\title{
Urban Green Space Degradation: An Experience of Kuala Lumpur City
}

\author{
Mohd Johari Mohd Yusof \\ Department of Landscape Architecture, Faculty of Design and Architecture \\ Universiti Putra Malaysia, 43400 Serdang, Malaysia \\ Tel: 6-03-8946-4091_E-mail: m_johari@upm.edu.my \\ Helmi Zulhaidi Mohd Shafri \\ Department of Civil Engineering, Faculty of Engineering \\ Universiti Putra Malaysia, 43400 Serdang, Malaysia \\ Tel: 6-03-8946-6459Ｅ-mail: helmi@upm.edu.my \\ Junainah Abu Kasim (Corresponding Author) \\ Department of Landscape Architecture, Faculty of Design and Architecture \\ Universiti Putra Malaysia, 43400 Serdang, Malaysia \\ Tel: 6-017-636-1203Ｅ-mail: junainah_UTM@yahoo.com
}

Received: November 16, 2018 Accepted: December 4, 2018 Published: December 19, 2018

doi:10.5296/emsd.v8i1.13917～URL: https://doi.org/10.5296/emsd.v8i1.13917

\begin{abstract}
Recently, Kuala Lumpur (KL) urban green space essentially was converted to artificial surface due to the urbanization process. The scarcity land in the city besides government new initiatives on infrastructure and affordable housing scheme has put an extra demands and request for developments to enter green spaces zone throughout the city's boundary. This study aims to review the literature on green space issues in KL, as well as to explore the use of Geographical Information System (GIS) that could provide a comprehensive and reliability information of green space predominantly used by urban planners and decision makers. There
\end{abstract}


is a need for Kuala Lumpur City Hall (DBKL) to map and monitor the gazetted green spaces changes aided by advance technology to ensure the city were plan well and developed in a sustainable way. The technology is extensively used for managing, controlling and mapping the urban green spaces changes and effectively use as an aided tool for planners in planning the green space developments effectively.

Keywords: Urban Green Space, Sustainability, Green Space Degradation, GIS

\section{Introduction}

Sustainability is the principles of living between human well-being and planet earth. According to The United Nation's 1987, Report of The World Commission on Environment and Development noted that to ensure the biological system of this planet remain sustain, it is important for the sustainable development balancing the needs of the present with the future generations well-being. Derivation from the SDGs targets, urban green space is part of the main contributor to the sustainable development agenda and as a comprehensive tool to serve a long-term protection of environmental sustainability for the city (Haq, 2011). It is a natural element that is responsible to ensure the quality of life in urban areas remains functional. Over years ago, green space within the cities play a role as an urban lungs, discharging oxygen to reduce the city's heat, and the wall for harmful air pollution (Anguluri \& Narayanan, 2017). However, despite the benefits offering by the green space to city environment enhancement, rapid urban development has led to the destruction of green space and driving the city unsustainable (Nur Syafiqah et.al, 2018). Just as other land use activities, the way of green space preserved, control and manage can cause an environmental impact for instance flood, destruction of natural habitats and climate change (Kim, Lee, \& Sung, 2016). Thus, it is very important for developing countries to race for the greenest city and to protect our mother of earth in order to create such a great livable place for human to live in.

The World Health Organizations (WHO) has defined urban green space as any open piece of land that is undeveloped and covered by vegetation in urban area that represents a fundamental element that contributing to human health improvement. The WHO also has suggested that for city to achieve a sustainable targets achievement, a city should require minimum 9 square metres of green space per person as an international baseline standard. Referring to Figure 1, Malaysia nearest neighbour, Singapore which is the third-densest city in the world, has providing 66 square metres of green space per inhabitant which is above the WHO standard (The Siemens Green City Report, 2011). The city has paid for every green space development sites with implementation of green roofs, cascading vertical gardens and mandatory to push go green in new construction as well as green material building initiatives (Roth and Chow, 2012) 


\section{Macrothink}

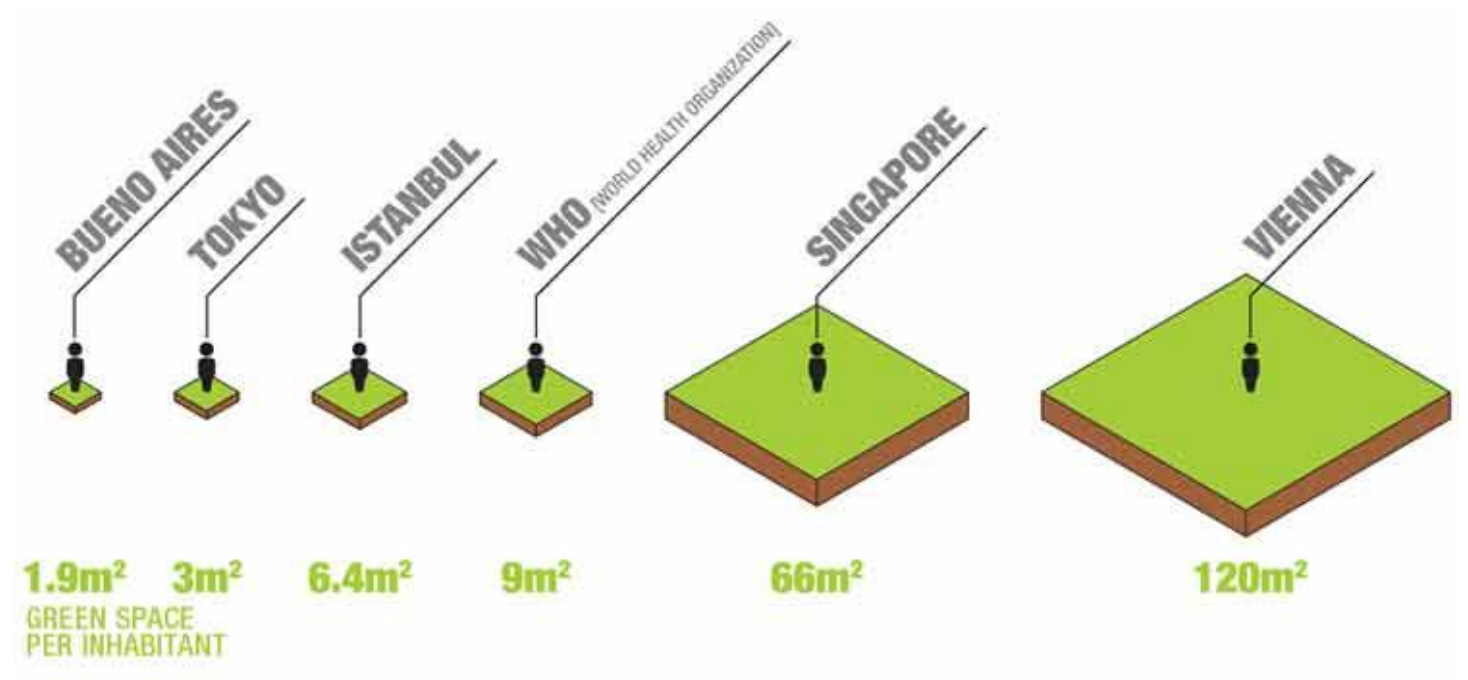

Figure 1. Green Space per Inhabitant in Developing Countries

However, the uncontrolled population growth per year has a significant to increasing number of developments in urban areas thus green space were sacrificed for more buildings. To date, the United Nations estimate there are 3.5 billion people lives in the city and was forecast almost 60 per cent of the world population will entered urban areas by 2030 . The high density of cities contributes to the rapid development activity with high pressure demand for new settlements, sustainable transport system, expanding the facilities services and high quality of living environment as a total benefit for urban dwellers (Che Khalid, 2014). Understand the trend of urbanization; the green space is seemed as the merely potential space to be developed in a compact city (Burgess and Jenks, 2000, p.15). Even though, the urban planners and related professional are very responsive to plan and adequate people's need, however it is important to proactively plan for preserving the city's natural resources. The green space is now depends on the importance they are given in land-use planning in a city and not to be existed as part of the natural functionality natural system (Koomen \& Dekkers, 2013).

As developing countries, Malaysia especially Kuala Lumpur (Figure 2) which is the fastest growing metropolitan area of the country, no exception from received the impact of urban growth events. In the year 2000, the population for Kuala Lumpur was forecast to reach 2.2 million by 2020 (DBKL, 2002). However, referring to Table 1, the United Nation of World Urbanization Prospects reported that Kuala Lumpur's 2018 population is now estimated at 7.5 million and by 2020 it will reach up to 7.9 million which is over than the projected target in KLSP 2020. Though, the huge differential of population percentage in actual and plan bring challenges for the Kuala Lumpur City Hall to manage and control the urban expansion. According to Kanniah (2017), Kuala Lumpur population density caused the degradation of green space per capita which is from 13 square meters per inhabitants in 2010 dropping to 8.5 square meters in 2014. Thus, Kuala Lumpur has been categorized as below international standard for sustainable city index. This uncontrolled urbanization not only gives a high pressure upon the city's environment, especially for green space area but as well has led to the illness of urban climate change in Malaysia cities (Isa, Naim, \& Salleh, 2017) 


\section{Macrothink}

Regarding on the statement above, the intention then is need to expediate and explore more on the degradation of the green space issue particularly in the developing country such as Kuala Lumpur, Malaysia. The aims of this paper is to review the literature on the green space issues in KL and how it was effected by the urban developments, as well as exploring technology such as Geographical Information System (GIS) which could help to monitor and control the green space preservation in this city.

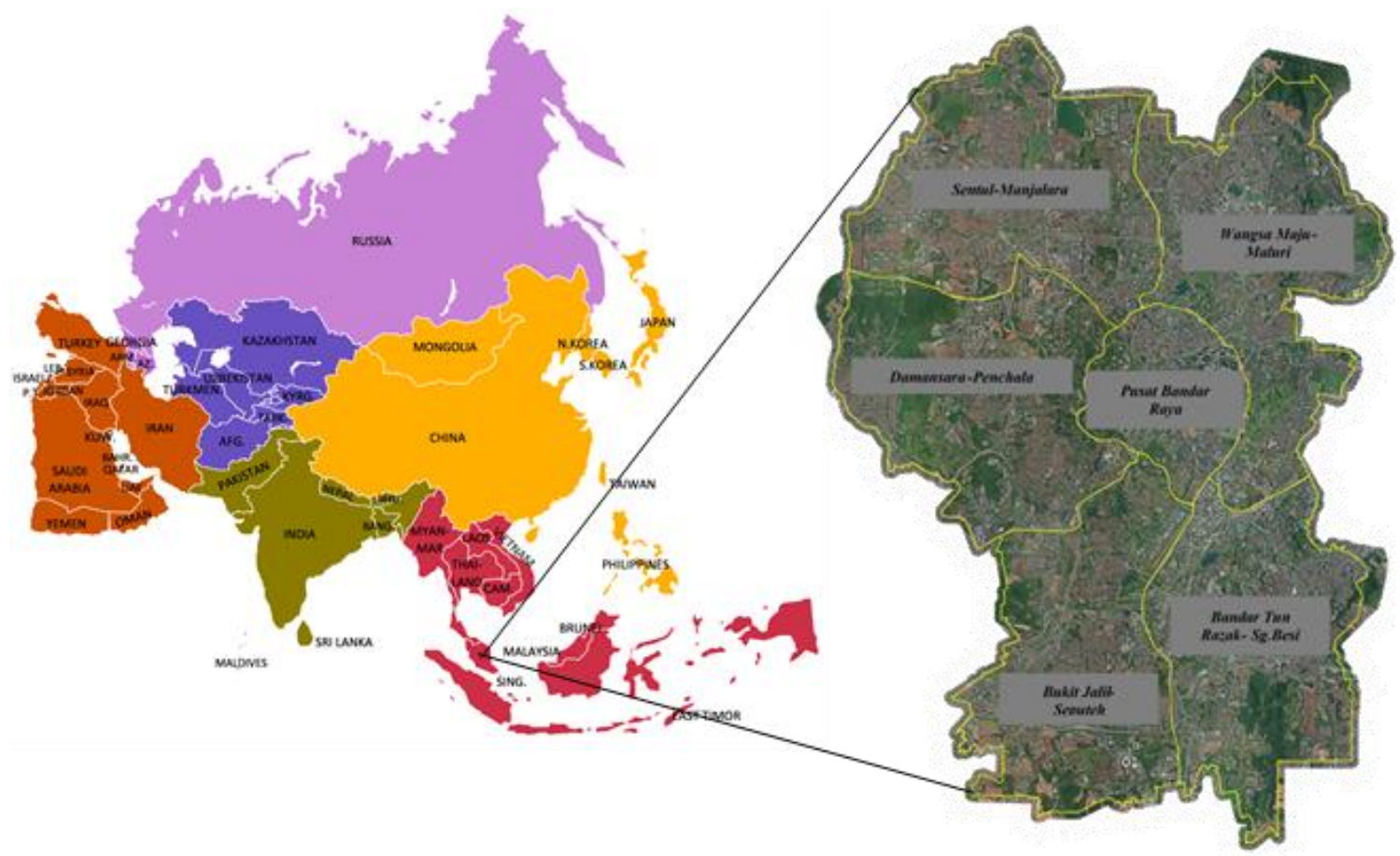

Figure 2. Kuala Lumpur Location on the Central West of Peninsular Malaysia with Acreage $243 \mathrm{~km}^{2}$

Table 1. Kuala Lumpur Population Data (Urban Area)

\begin{tabular}{llll} 
Year & Population & Growth Rate (\%) & Growth \\
\hline 2035 & $10,466,823$ & $1.31 \%$ & 661,574 \\
\hline 2030 & $9,805,249$ & $1.73 \%$ & 804,969 \\
\hline 2025 & $9,000,280$ & $2.39 \%$ & $1,003,450$ \\
\hline 2020 & $7,996,830$ & $2.82 \%$ & 432,918 \\
\hline 2018 & $7,563,912$ & $3.35 \%$ & 712,481 \\
\hline 2015 & $6,851,431$ & $3.35 \%$ & $1,041,478$ \\
\hline 2010 & $5,809,953$ & $3.35 \%$ & 883,166 \\
\hline 2005 & $4,926,787$ & $3.36 \%$ & 750,318 \\
\hline 2000 & $4,176,469$ & $7.02 \%$ & $1,201,508$ \\
\hline 1995 & $2,974,961$ & $7.24 \%$ & 877,300 \\
\hline 1990 & $2,097,661$ & $8.00 \%$ & 670,234 \\
\hline 1985 & $1,427,427$ & $8.00 \%$ & 455,982 \\
\hline
\end{tabular}




\section{Methods}

This study was based on a review of multiple disciplines of papers which consists of five cores of KL government report and documents, seven were published in proceeding and remaining were scientific studies. This study intention is to apply a systematic and structured review from various field of research concerning on degradation of urban green space to a city under rapid urban development's particularly focusing on KL case study. The first task was to find the area of research by using information sources such as Scopus, Web of Sciences and ProQuest, defining the information needs in keywords and screening the words in abstract and the title. Referring Table 2, the selection of relevance articles was analyzed based on web of sciences categories and frequent keywords use according to author's view as well as referring in diverse scientific literature. Most of the information was accumulated from year 2000 until 2017 from multiple area of research for instance in urban planning, urban environmental engineering, landscape architecture, society and space as well as sustainable development. The general output and relevant finding was identified and restructured according to this study purpose. The related government initiatives, a blue-print and strategies also were included to get a valuable, different meaning and practices information regarding on green space developments.

Table 2. Web of Sciences Categories and the Most Frequent Keywords Used by Author

\begin{tabular}{|c|c|c|c|c|}
\hline Rank & Web of Sciences Categories & $\begin{array}{l}\text { Number } \\
\text { of Papers }\end{array}$ & Examples on Green Space's Topic & Idea of Keywords \\
\hline 1 & Urban Planning & 1597 & $\begin{array}{l}\text { - Urban green spaces in the compact cities } \\
\text { - Quantify green space } \\
\text { - Impacts of population density on green space }\end{array}$ & \multirow{10}{*}{$\begin{array}{c}\text { Urban green space (UGS) } \\
\text { Densification green space } \\
\text { Shrinking green space } \\
\text { Green space management } \\
\text { Urban Greeneries } \\
\text { Land use } \\
\text { Land use land cover } \\
\text { (LULC) } \\
\text { GIS UGS }\end{array}$} \\
\hline 2 & Land Use & 973 & $\begin{array}{l}\text { - Effect urban expansion towards green } \\
\text { - Urban land expansion } \\
\text { - Impact urban growth to green spaces }\end{array}$ & \\
\hline 3 & Ecological Indicators & 868 & $\begin{array}{ll}\text { - } & \text { Availability of green spaces } \\
- & \text { Urban dynamic on green space developments } \\
- & \text { Planned the UGS }\end{array}$ & \\
\hline 4 & Urban Greening & 767 & $\begin{array}{l}\text { - Urban green spaces and well being } \\
\text { - Use of green space in urban planning } \\
\text { - Estimating green space production }\end{array}$ & \\
\hline 5 & Geography & 529 & $\begin{array}{ll}\text { - } & \text { Urbanization process towards UGS } \\
\text { - Nature for urban development } \\
\text { - }\end{array}$ & \\
\hline 6 & Urban Studies & 508 & $\begin{array}{l}\text { - Land changes } \\
\text { - Challenges urban green space development } \\
\text { - Cities and urban form use on green space sites }\end{array}$ & \\
\hline 7 & Environmental Sustainability & 175 & $\begin{array}{l}\text { - Restoring ecosystems } \\
\text { - Urban environments for future economy } \\
\text { - Urban ecology and urban ecosystems }\end{array}$ & \\
\hline 8 & Urban Climate & 168 & $\begin{array}{l}\text { - Loss green space increase city heat } \\
\text { - Greens Initiatives and method for increase } \\
\text { - Urban surface }\end{array}$ & \\
\hline 9 & Environmental Management & 159 & $\begin{array}{l}\text { - Low carbon land development by greening } \\
\text { - Protecting and restoring greenery in a city } \\
\text { - Forecasting of green space reduction }\end{array}$ & \\
\hline 10 & Remote Sensing Application & 84 & 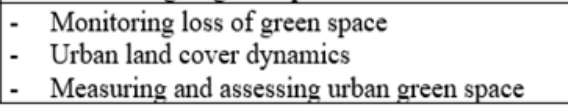 & \\
\hline
\end{tabular}




\section{Findings}

\subsection{When KL'Green Space is Not Equal to Green}

Green areas in a city are the foundation of the natural productivity in the urban structure. It plays a vital role in our city's health. Even looking at the greenery view will make you feel better. That is how the green area contribute to the city's urban fabric which make the people live in that area received a good emotional feeling (Mansor \& Said, 2008). These assets are also valuable to enhance city's beautification, catalyst for health improvement, the generator of social interactions and balancing the environment (DBKL, 2002). However, the urban green area is invaded by the skyscraper development and continues to be destroyed to meet the interests of some individuals and organizations purpose (Waldner, 2009). Furthermore, urban green space mainly become a potential site or an area to be developed (Chiesura, 2004) and become major source for the economic investment (Lichtenberg, 2011). The only 'left-over space' in urban setting brings the opportunity for the extension of urban boundary, generate high density of population and increase the intensity of the development. This presents a number of impacts and challenges especially for urban planner to adequate a comfortable housing, public facilities, better infrastructure, and electricity supply.

According to Nor et al. (2017), in most of the developing countries urban green space has declined due to the rapid urban expansion as many of the space has been giving away for the residential, commercial and industrial development activity. The continuous and uncontrolled development trend will affect too many fragmentation and disturbance towards urban dwellers well-being such as floods, air and noise pollution and social and health issues (Mansor \& Harun, 2014; Ren et al., 2017). As urban areas have expanded, in the views of some authors they have sometimes even posed threats to the environment of the whole planet (Riffat, Powell \& Aydin, 2016). Jafari et al. (2017) have therefore suggested that urban development should aim to be more self-sufficient in its use of resources rather than depleting resources drawn from areas outside the city. Within this context, it can be argued that green spaces should not be seen as merely the 'left-over' spaces that have not yet been developed within an urban area, but as spaces which function as part of the life-support system of the city and which benefit the urban dwellers through providing them with better surroundings in which to live and work and hence to enjoy a better quality of life.

In Malaysia, especially Kuala Lumpur (Figure 2), tremendous change in the land use activity in Kuala Lumpur was rapidly occurred since year 1974 when Kuala Lumpur firmly was declared as Federal Territory Administrative area and was expanded to $243 \mathrm{~km}^{2}$ from its based area in year 1860 that only $0.65 \mathrm{~km}^{2}$ (Figure 3). Since that year, more development starting levitated especially in the city centre zone impact from the migration activity (Awang Besar et al. 2014). Uncontrolled development driven by high population density has flush down most of the green space in the city. According to the previous research conduct in year 2017, even statistically shows the green space coverage in Kuala Lumpur has increase by $4 \%$ which is from 6,215 ha in 2014 to 7,310 ha in 2016 due to the implementation of "Greening KL Programme" through Malaysia Economic Point Project (Kanniah \& Chin, 2017), however if look at the green cover percentage in particular forested area in Kuala Lumpur, it was $9 \%$ loss 
out of its gazetted zone (Kanniah, 2017). Yakob, Yusof \& Hamdan (2012) study also approved that green space in Kuala Lumpur are mostly has being converted to residential area in order to achieve the sustainable urban housing development programmed.

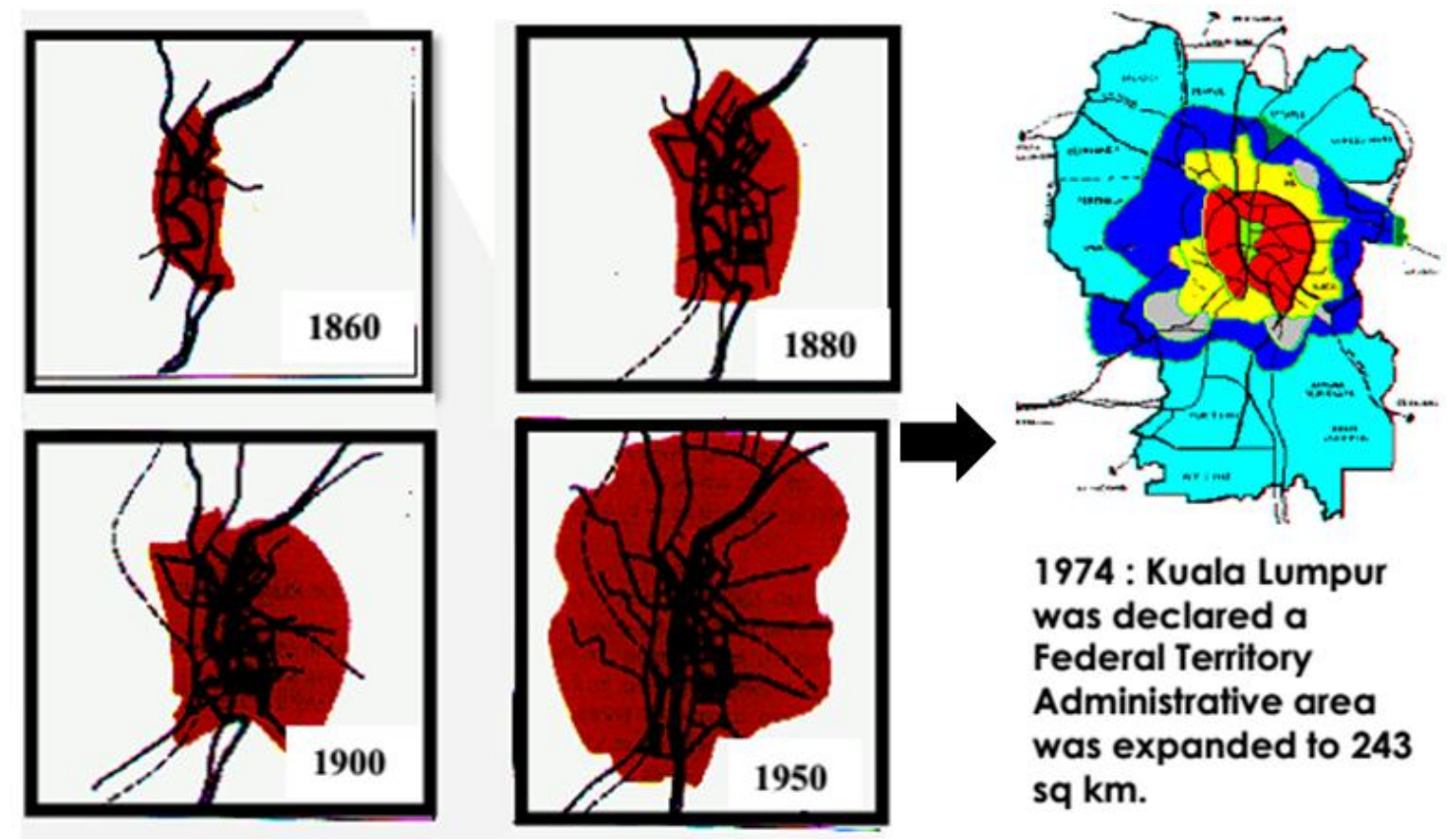

Figure 3. Kuala Lumpur Development Changes Pattern

Thus, throughout the years, the disappearance of urban green space remains gained attention from local residents protesting in media. Newspaper articles have revealed the fact that reporting on the current controversies for instance issues at Taman Bukit Kiara and Bukit Gasing (Berita Harian, 2017; Tan, 2015). Taman Bukit Kiara is one of the gazetted green area that should be preserved under Kuala Lumpur Structure Plan 2020 strategies (DBKL, 2002), yet it has transform into mix-use development with the six-lane road construction project that connecting the Penchala Expressway towards Kuala Lumpur. Harian Metro (2017) reported that, local residents in Taman Tun Dr. Ismail have submitted 500 petitions to DBKL to show their protest towards the loss of green spaces. Besides Bukit Kiara, Bukit Gasing which is the merely green lung left in Kuala Lumpur has partially flash down for the development benefits. Tan (2015) highlighted the issue on slope fails and road surface harm nearby Bukit Gasing that effected from the hilly bungalow development project. These green areas are neglected to be preserved as per designated in future master plan. The acquisitiveness of development not only rescinds the natural resource in the city but also destructed recreational facilities. Besides, Yahya (2018) also has highlighting on football field issue in Bandar Tun Razak that will develop into affordable housing scheme project. Those issues risen by urban dweller's purposely is not only to protect their green space but most concerning on city's environment and awareness to their health.

\subsection{Changes in Gazzeted Green Space Zones and Mechanism to Controlled in Urban Planning}

The scarcity land in the city has put an extra demands and request for developments to enter 
gazetted green spaces zone. According to Kanniah (2017), the continuing population resided in KL has put the strong pressure of various kinds, including political decision which force for allowing the restricted zones to be developed particularly for affordable housing. Referring to this study, there are 24.5 hectares of gazetted green space were recorded lost from 2015 and 2016 and most of the loss area occurs in public parks. A well-adjusted assessment is required in protecting green spaces in a city because it is not easy to provide a balanced mechanism between population demand and land supply. Therefore, there is a need for urban planner to have a systematic tool to control such development pressure. One of the strategic approaches that have been use for many years in urban planning is land-use zoning plan. This classical approach has been used for many years (Calkins, 1979) which provides a strong pillar for local spatial planning development in term of promoting high benefit of socioeconomic impact towards city's dweller (Qian 2013). However, it is been criticizes as failed to be practically implement as per design in master plan, thus called as 'game theory' (Lin \& Li, 2016). For instance, according to Barreto \& Drummond (2017), to overcome the detriment of reserved land, the management of land use zoning should be use as a strategic formulation and strategic competitiveness approach to ensure a better protection of preservation area zones. This is agreed by Nicolle \& Leroy (2017) where the protected areas are safe not by the zoning plan but according to the type of conservation purpose and common objectives from various professional fields, thus depending with top-down governmental choices. In a context of urban planning practices in Malaysia, according to Taib \& Chin Siong (2008), development plan plays an important role in urban planning process and zoning is part of the instrument that functioning as urban controlling system. This is agree by Abdullah, Harun, \& Abdul Rahman (2011) stated that zoning is require to manage the land and it is a strategic approach for planning control.

However, for Kuala Lumpur it is crucial to practice zoning plan as main tool to control development as the City Plan are still not gazetted (since 2008 till October 2018) due to the rapid changing of land value in the city (Thomas, 2017). Thus, within this context of argument, can be conclude that if not zoning, what other form of land use management tool that is suitable to control the urban development in Kuala Lumpur and indirectly mitigate the loss of green space? This argument can be debates by referring to the traditional planning theory developed by Calkins (1979). He has stated that to monitoring the planning development in a city should consist of two major parts which are comes from rational zoning plan supportive by the technology information system that could give a high assessment in evaluating the development plan. This author has presenting 'planning monitor' to identify the difference between what is plan and actual by using algebra. Calkin's theory then has been expanded by Talen (1996) who stated that planners are more focusing on designing stage rather that evaluate the impact of the action taken. This study applied Geographical Information System (GIS) and statistical analysis to find out the actual spatial distribution of public facilities after the implementation of the plan in Colorado. His study shows, what has been plan did not match with the policy and original intent. Furthermore, the lack of systematic evaluation of the plan implementation is one of the factors contributing to the failure of the planning process (Yaakup et al. 2005). This author pointed out that to control the development of city require an effective approach which are enabling to evaluate 
the formulation of plan as well as controlling the development expansion.

\subsection{Application of Geographical Information System (GIS) and Remote Sensing for Monitoring Urban Green Space}

Geographical Information System (GIS) has been applied in many field and practises including in detecting the changes of land use and land cover. The technology is extensively used for managing, controlling and mapping the urban green spaces changes and effectively use as an aided tool for planners in planning the green space developments. In the context of planning for green spaces in Kuala Lumpur, Johari (2012) suggested urban planners require a high validity and up to date database by using GIS supporting with the high resolution imagery in order to get a transparency information as well as to produce a systematic inventories of green spaces. GIS provide a practical solution in planning fields and widely applied in monitoring and mapping the land use. In late 1998, Mac Leod \& Congalton has list four main aspects that need to consider when monitoring the land changes: 1) the events occurred can be detecting and seen; 2) need to identify the changes; 3) investigate and measuring the extend of the change; 4) assessing the spatial changes. In line with the technology update, these aspects can be efficiently carried out during the land changes assessment with the advance functional of GIS application merging with remote sensing techniques as per use by many scholars in the world. In the city of Addis Ababa, Ethiopia, to perform a high detection on green space changes, the high resolution of satellite imagery has been used to detect the changes radiances of the land surface which can remotely sensed. Abebe and Megento, 2016 has proved the city of Addis Ababa has loss their urban green spaces with annual rates $5.9 \%$ over 30 years.

In Kuala Lumpur GIS has been used more than 10 years particularly in DBKL practises on land use database development as well as land lot updating. However, in monitoring the land changes which involved the analysis aspects, the local authority are not capable to carry out the asessment due to the lack of spatial database and be contingent on the manual inventory record. Thus many local scholars and GIS expert has an effort to help the local authority to have a digital view on the city land use changes event. One of the valuable study conducted by Johari (2012), has focusing on the green space loss in KL by using GIS software emerging with the high resolution imagery data. The remote sensing data sources was obtained from the Malaysian Remote Sensing Agency under Ministry of Energy, Science, Technology, Environment and Climate Change. He has used object-based segmentation method to classified and quantified the left-over green space in KL. The study revealed that, the green space in KL only covers $143.86 \mathrm{~km}^{2}$ out of $243 \mathrm{~km}^{2}$ of KL. Similar study conducted by Noor et al. (2013) which has developed a GIS based techniques for mapping green space changes by using three series of remote sensing images for year 1990, 2001 and 2010. The findings illustrate the city has decrease in its green space ratio due to the pressure of urban developments. Furthermore, recents study by Kanniah (2017) has used GIS software merging with the Carnegie Landsat Analysis System-algorithm (CLASlite) and processing the images thru the mixed-pixel detection analysis. The techniques has improve the output of the green space changes statistic due to the $90 \%$ accuracy has been recorded by the classified landsat images. The findings illustated KL's green space has tramendously decrease by $3 \%$ from 
6,564 hectare in 2001 to 5,891 hectare in 2013. To the above examples indicate how the GIS supporting by the high resolution satellite imagery might increase the capacity of the urban planner's work output as well as could use to monitor, mapped with the valuable green space identity information recorded in the database. These approach and technique could be a great initiaitives for the effort and plan of the conservation of green spaces in the well establish city like KL. The information gathered from the high resolution imagery then can be a based map to verify and update the conventional mapping layerset.

In developing countries, the use of GIS for green space mapping is already been develop (Yaakup et al. 2005). The technology gives a new platform for managing the city resources with enabling the view on the monitor screen, thus reduce the manpower requirements on sites inventory. For example in Lisbon, Portugal have develop the GIS database of green urban areas at the city scale and mapping the presented of green initiatives program that has implemented. The aims is to provide the relevance information in monitoring the actions of master plans and strategies targeted at the planned location. These give a valuable and quickly information in informing decision-making processes with less assessment carry out on site and time consuming. In Kuala Lumpur, Johor Bahru and Georgetown, the use of GIS is already matured and widely practises by their planning departments. The GIS database on green spaces are more concentrately on locations, status of land and its types, but not about the future or potential sites could be recognised as future green spaces.

The very high resolution (VHR) of sattelite imagery now become an important source for measuring urban growth. The use of this imagery source aided with GIS application showed the advance innovation in controlling the green space degradation issues. The USA satellite programs for instance GeoEye, QuickBird, IKONOS as well as WorldView gives us a real world imagery with ground accuracy distance up to $15 \mathrm{~km}$ (Michel, Youssefi, \& Grizonnet, 2015). However, for urban studies, the high resolution imagery are needed to detect the small patches object particularly for green space analysis. The use of aerial imagery could detect the finest object up to $20 \mathrm{~cm}$ (Tarantino \& Figorito 2011). The studies using such sources were conducted mostly in Europe and expanding to Asia. For example, using superpixel images Rumiana et al. (2016) has succesfully extract 15 land use classess with an overall 49\% proportion of tree cover has been detected, while Lee, Cheng \& Li (2010) use the aerial orthophotos to tracing and segmented a shoreline green areas with the accuracy classify level was found to be around $1.5 \mathrm{~m}$ as well as could demonstrate a real location view.

The review on previous pulished research on the use of GIS application associated with remote sensing as well as aerial images highlights that the technology advance could provide a comprehensive extraction of green space thus increase the reliability of the information. The distribution of green space and recognization of the difference types of green space could easily obtain across a city such as KL. However, the capacity of hardware as well as the expertise in handling the various tools in GIS application can enhance the results of the green space distribution analysis. The various GIS data and layer set, such as population data, and gazetted land are needed to assist in green space mapping as well as to analyse the correlation between these spatial information. 


\section{Conclusion}

As a conclusion, there are so much goals, strategies and objectives have been developed to ensure the sustainable development approach can achieve its vision. The relevant researchs on benefits, needs and promotion of urban green spaces towards sustainability has been widely piloted. The agenda and findings are stereotypically assume that more green spaces is good for a city but how specific their contribution to maintain, restore and preserve this assets for future generations. Their future natural resources is most probably ultimately with redevelopment. The inquiries is where should urban planners and landscape designers need to plan and eduquate more green spaces in or at appropriate location that may be unambigously good in term of ecological, human well-being and to end with contribute to the SDG's goals as a total.

Kuala Lumpur regulation, plan policies and ordinance should inclusive and compatible to use for any land uses;commercial,residential,industrial, including green space with equally. Even though the implementation of the guidelines and the planning policy are difficult to measured and assess, but the respect to the documents practises need to obey. The local authority should aggressively declare to gazetted more potential green spaces in the city by enabling new technology for used in controlling, monitoring and well design of zoning plan and directly could enhances ecosystem services before it was easily disappeared from the urban landscape.

Furthermore, this study suggested that by using technology advanced such as GIS, it could give a high accuracy of evidence as well as could play an important role in controlling urban development in KL. By using an advance technique such as object-based segmentation to classify the green space could help the authority to enhance understanding and condition the nature of remaining green space in the city. Therefore, by these informative data could allow planner to defend decision on preserving green space and plan the city with more sustainability. Eventhough, the aerial imagery offer a high cost to obtain, but it could give a transparency output as well as could increase the effectiveness in gathering the land information due to understand the events. The up-to-date information gather from the technology could enhance the genuine green space data thus improve the decision-making process as well as more potential green space easily could recognize and been gazetted by them.

\section{Acknowledgement}

The research is financed by IPS Putra Grant Research (GP-IPS/2017/9586600), Universiti Putra Malaysia, and KL City Hall Scholarship for the research funding assistance through this study conducted. We also want to thank the Planning Department of KL City Hall (JPRB, DBKL) for providing the information as well as the database. I extend my thanks to Associate Professor Dr. Helmi Zulhaidi Mohd Shafri from the Engineering Department, Universiti Putra Malaysia for his help with GIS knowledge and advice on the research literature.

\section{References}

Abdullah, A., Harun, Z., \& Abdul Rahman, H. (2011). Planning Process of Development 
Project in the Malaysian Context: A Crucial Brief Overview. International Journal of Applied Science and Technology, 1(2), April 74-81.

Abebe, M., \& Megento, T. (2016). The City of Addis Ababa from 'Forest City' To 'Urban Heat Island': Assessment of Urban Green Space Dynamics. Journal of Urban and Environmental Engineering, 10(2), 254-262. https://doi.org/10.4090/juee.2016.v10n2.254262

Anguluri, R., \& Narayanan, P. (2017). Role of Green Space in Urban Planning: Outlook Towards Smart Cities. Urban Forestry \& Urban Greening, 25, 58-65.

https://doi.org/10.1016/j.ufug.2017.04.007

Asmani, F. (2017, November 17). Belum Muktamad. Harian Metro. [Online] Available: https://www.hmetro.com.my

Awang Besar, J., Fauzi, R., Saifude Ghazali, A., Abdul Ghani, M., \& Baharum, Z. (2014). Kuala Lumpur dan Cabaran Baru Pembangunan Berterusan. Malaysian Journal of Society and Space, 10(6), 75-85. [Online] Available: http://ejournal.ukm.my/gmjss

Barreto, C. G., \& Drummond, J. A. (2017). Strategic planning in Brazilian protected areas: Uses and adjustments. Journal of Environmental Management, 200, 79-87.

https://doi.org/10.1016/j.jenvman.2017.05.064

Calkins, H. W. (1979). The Planning Monitor: An Accountability Theory of Plan Evaluation. Environment and Planning A: Economy and Space, 11(7), 745-758.

https://doi.org/10.1068/a110745

Che Khalid, N. (2014). Urban Greeneries in Malaysia: The Barriers and Opportunities (Unpublished doctoral dissertation). University of Melbourne.

Chiesura, A. (2004). The role of urban parks for the sustainable city. Landscape and Urban Planning, 68(1), 129-138. https://doi.org/10.1016/j.landurbplan.2003.08.003

DBKL (2002). Kuala Lumpur Structure Plan 2020 (Malaysia, Kuala Lumpur City Hall, Kuala Lumpur). Kuala Lumpur, W.P.Kuala Lumpur

Emily, T. (1996). After the Plans: Methods to Evaluate the Implementation Success of Plans. Journal of Planning Education and Research, 16(2), 79-91.

https://doi.org/10.1177/0739456X9601600201

Friederich, J., Jaunky, G., Xu, R., \& Vohra, M. (2011). Asian Green City Index: Assessing the environmental performance of Asia's major cities. [Online] Available:

http://sg.siemens.com/city_of_the_future/_docs/Asian-Green-City-Index.pdf

Haq, S. M. (2011). Urban Green Spaces and an Integrative Approach to Sustainable Environment. Journal of Environmental Protection, 02(05), 601-608.

https://doi.org/10.4236/jep.2011.25069

Isa, N., Naim, W., \& Salleh, S. (2017). Urban Climatic Analysis Mapping of Kuala Lumpur City. Pertanika Journal of Social Science and Humanities, 25(February), 291-300. [Online] Available: https://mc.manuscriptcentral.com/upm-jssh. 
Jafari, E., Soltanifard, H., Aliabadi, K., \& Karachi, H. (2017). Assessment of the Effect of Neyshabur Green Spatial Configuration on the Temperature of Land Surface and Heat Islands. Open Journal of Ecology, 07(09), 554-567. https://doi.org/10.4236/oje.2017.79037

Johari, M. Y. (2012). The True Colours of Urban Green Spaces: Identifying and Assessing the Qualities of Green Spaces in Kuala Lumpur, Malaysia (Unpublished doctoral dissertation). University of Edinburgh.

Kanniah, K. D. (2017). Quantifying green cover change for sustainable urban planning: A case of Kuala Lumpur, Malaysia. Urban Forestry \& Urban Greening, 27, 287-304.

https://doi.org/10.1016/j.ufug.2017.08.016

Kanniah, K. D., \& Chin, S. H. (2017). Urban Forest Cover Change and Sustainability of Malaysian Cities. Chemical Engineering Transactions, 56, 673-678.

Kim, H., Lee, D., \& Sung, S. (2016). Effect of Urban Green Spaces and Flooded Area Type on Flooding Probability. Sustainability, 8(2), 134. https://doi.org/10.3390/su8020134

Koomen, E., \& Dekkers, J. (2013). The Impact of Land-Use Policy on Urban Fringe Dynamics. Modeling of Land-Use and Ecological Dynamics, 9-35.

https://doi.org/10.1007/978-3-642-40199-2_2

Lee, I., Cheng, L., \& Li, R. (2010). Optimal Parameter Determination for Mean-Shift Segmentation- Based Shoreline Extraction Using Lidar Data, Aerial Orthophotos, and Satellite Imagery. In The American Society for Photogrammetry and Remote Sensing (ASPRS) 2010. [Online] Available: https://www.asprs.org/

Lichtenberg, E. (2011). Open Space and Urban Sprawl: The Effects of Zoning and Forest Conservation Regulations in Maryland. Agricultural and Resource Economics Review, 40(03), 393-404. https://doi.org/10.1017/S1068280500002859

Lin, J., \& Li, X. (2016). Conflict Resolution in The Zoning of Eco-Protected Areas in Fast-Growing Regions Based on Game Theory. Journal of Environmental Management, 170, 177-185. https://doi.org/10.1016/j.jenvman.2015.11.036

Macleod, R. D., \& Congalton, R. G. (1998). A Quantitative Comparison of Change Detectional Algorithms for Monitoring Eelgrass from Remotely Sensed Data. Photogrammetric Engineering \& Remote Sensing, 64, 207-216.

Mansor, M., \& Harun, N. Z. (2014). Health Issues and Awareness, and the Significant of Green Space for Health Promotion in Malaysia. Procedia - Social and Behavioral Sciences, 153, 209-220. https://doi.org/10.1016/j.sbspro.2014.10.055

Mansor, M., \& Said, I. (2008). Green Infrastructure Network as Social Spaces for Well-Being of Urban Residents in Taiping, Malaysia. Jurnal Alam Bina, 11(2), 1-18. [Online] Available: https://www.researchgate.net/publication/228461692

Michael, J., Mike, J., \& Rod, B. (2000). Compact Cities: Sustainable Urban Forms for Developing Countries. [Online] Available: http://books.google.com 
Michel, J., Youssefi, D., \& Grizonnet, M. (2015). Stable Mean-Shift Algorithm and Its Application to the Segmentation of Arbitrarily Large Remote Sensing Images. IEEE Transactions on Geoscience and Remote Sensing, 53(2), 952-964.

https://doi.org/10.1109/TGRS.2014.2330857

Nicolle, S., \& Leroy, M. (2017). Advocacy coalitions and protected areas creation process: Case study in the Amazon. Journal of Environmental Management, 198, 99-109. https://doi.org/10.1016/j.jenvman.2017.04.035

Noor, N. M., Abdullah, A., \& Manzahani, M. N. (2013). Land Cover Change Detection Analysis on Urban Green Area Loss Using GIS and Remote Sensing Techniques. Planning Malaysia Journal, 11(3).

Nor, A. N., Corstanje, R., Harris, J. A., \& Brewer, T. (2017). Impact of rapid urban expansion on green space structure. Ecological Indicators, 81, 274-284.

https://doi.org/10.1016/j.ecolind.2017.05.031

Nur Syafiqah, A. S., Abdul-Rahim, A. S., Mohd, J. M. Y., \& Tanaka, K. (2018). An Economic Valuation of Urban Green Spaces in Kuala Lumpur City. Pertanika Journal of Social Sciences \& Humanities (JSSH), 26(1), 469-490

Qian, Z. (2013). Master Plan, Plan Adjustment and Urban Development Reality Under China's Market Transition: A Case Study of Nanjing. Cities, 30, 77-88.

https://doi.org/10.1016/j.cities.2011.12.010

Radoux, J., \& Defourny, P. (2008). Gis-Driven Classification of Satellite Imagery. The International Archives of the Photogrammetry, Remote Sensing and Spatial Information Sciences, XXXVIII-4/C7. [Online] Available: www.isprs.org/proceedings

Ren, Y., Qu, Z., Du, Y., Xu, R., Ma, D., Yang, G., ... Chang, J. (2017). Air Quality and Health Effects of Biogenic Volatile Organic Compounds Emissions from Urban Green Spaces and The Mitigation Strategies. Environmental Pollution, 230, 849-861.

https://doi.org/10.1016/j.envpol.2017.06.049

Riffat, S., Powell, R., \& Aydin, D. (2016). Future Cities and Environmental Sustainability. Future Cities and Environment, 2(0), 1. https://doi.org/10.1186/s40984-016-0014-2

Roth, M., \& Chow, W. T. (2012). A Historical Review and Assessment of Urban Heat Island Research in Singapore. Singapore Journal of Tropical Geography, 33(3), 381-397.

https://doi.org/10.1111/sjtg.12003

Rumiana, V., Ján, O., Atanas, K., Monica, K., Konstatin, R., \& Stefan, G. (2016, June). Mapping Urban Green Spaces Based on Remote Sensing Data: Case Studies in Bulgaria and Slovakia. In Proceedings, 6th International Conference on Cartography and GIS. [Online] Available: https://www.researchgate.net/publication/321490715

Taib, M., \& Chin Siong, H. (2008, June 26). Planning System in Malaysia. In Joint TUT-UTM Seminar of Sustainable Development and Governance. [Online] Available: http://epublication.fab.utm.my/154/1/Sustainable-Development0802.pdf 


\section{Macrothink}

Tan,V. (2015, March 30). Bukit Gasing Residents Object Proposed Projects. The Star. [Online] Available: https://www.thestar.com.my

Tarantino, E., \& Figorito, B. (2011). Extracting Buildings from True Color Stereo Aerial Images Using a Decision-Making Strategy. Remote Sensing, 3(8), 1553-1567.

https://doi.org/10.3390/rs3081553

Thomas, F. (2017, November 28). KLCP 2020 yet to be Gazetted. The Star. [Online] Available: https://www.thestar.com.my

Waldner, L. S. (2009). Into the black hole: Do local governments implement their spatial policies? Land Use Policy, 26(3), 818-827. https://doi.org/10.1016/j.landusepol.2008.10.011

Wolch, J. R., Byrne, J., \& Newell, J. P. (2014). Urban Green Space, Public Health, And Environmental Justice: The Challenge of Making Cities 'Just Green Enough'. Landscape and Urban Planning, 125, 234-244. https://doi.org/10.1016/j.landurbplan.2014.01.017

Yaakup, A., Abu Bakar, S., \& Bajuri, H. (2005, November). GIS Based Integrated Planning Assessment for Sustainable Land Use Development. In UiTM, National Planning Seminar. [Online] Available: http://citeseerx.ist.psu.edu.

Yahya, R. (2018, July 05). Penduduk Bantah Projek Perumahan 'Haram'. Utusan Online. [Online] Available: www.utusan.com.my/berita/wilayah/kl-putrajaya/penduduk- bantah-proje k-perumahan-haram-8217-1.703412

Yakob, H., Yusof, F., \& Hamdan, H. (2012). Land use Regulations Towards a Sustainable Urban Housing: Klang Valley Conurbation. Procedia - Social and Behavioral Sciences, 68, 578-589. https://doi.org/10.1016/j.sbspro.2012.12.250

\section{Privacy Statement}

The names and E-mail addresses entered in this journal's site will be used exclusively for the purposes of this journal and will not be made available for any other purpose or to any other party.

\section{Copyright Disclaimer}

Copyright for this article is retained by the author(s), with first publication rights granted to the journal.

This is an open-access article distributed under the terms and conditions of the Creative Commons Attribution license (http://creativecommons.org/licenses/by/3.0/). 